\title{
The usefulness of sugar beets for biogas production in relations of the storage time and sugar content
}

\author{
Natalia Mioduszewska ${ }^{1, *}$, Mariusz Adamski ${ }^{1}$, Anna Smurzyńska $^{1}$, Jacek Przybył ${ }^{1}$, \\ Krzysztof Pilarski ${ }^{1}$ \\ ${ }^{1}$ Poznań University of Life Sciences, Institute of Biosystems Engineering, Wojska Polskiego 28, \\ 60-637 Poznań, Poland
}

\begin{abstract}
The aim of the study was to evaluate the usefulness of sugar beet for biogas production, taking into account the duration time of storage and sugar content in the roots. The research has included analysis of methane and biogas yield of sugar beet. The relations between the sugar content in the roots and the length of storage period and the course of the methane fermentation process were determined. Sugar beets with sugar content of $17.6 \%$ and $19.6 \%$ were used for this experiment. In order to analyse the fermentation process, the fresh beets and the beets stored in flexible, hermetic tanks in the period of 43 and 89 days were used. Based on the analysis of the obtained results, it was found that the sugar content and the storage time of sugar beet roots can differentiate the production of biomethane and that it influences the methane fermentation process and the quality of the produced biogas.
\end{abstract}

\section{Introduction}

In Europe, sugar beets are the basic plant for the sugar production. The sugar market in the European Union was a regulated market since 2006, and sugar beet producers were subject to production limits [1]. From 1 October 2017, the existing regulations on the EU sugar market have ceased to apply [2]. Liberalization of the sugar market has increased farmers' interest in sugar beet production. Therefore, in the next few years it is possible to significantly increase the production and productivity of this crop. Currently, this is enable by the applicable law as well as due to the considerable potential of the industry involved in the production of sugar beet, i.e. the production of seeds, fertilizers, plant protection chemicals, specialized techniques and modern technologies [3-6]. However, from 2017 on, sugar beets will be traded at world market prices, which tend to vary greatly. Farmers will no longer be subject to stable financial support for traditional sugar beet production. The expiration of the EU sugar beet quota increases the necessity to consider an alternative utilization of sugar beets. Bringing sugar beets intended for bioenergy production into farmers' focus could be one opportunity to provide farmers with more planning certainty [2].

\footnotetext{
* Corresponding author: natalia.mioduszewska@,up.poznan.pl
} 
By the year 2020, 20\% of the total energy production in the European Union is to be from renewable resources [1,7-9]. One of the possibilities is the production of agricultural biogas. For example, in Germany, 52\% of the substrate used for biogas production are renewable primary products, including arable crops [7-8]. The alternative use of beet is part of the goal of the European Union's energy and climate package, which assumes the development of innovative and decentralized energy, with the use of energy from renewable sources of agricultural origin. In particular, the package provides actions for the development of distributed cogeneration based on local renewable energy resources and innovative technologies for their use, in particular for the development of agricultural biogas plants and energy agriculture in general [1, 7-9].

In the case of sugar beets, it is considered the most appropriate to use them for the production of bioethanol and biogas [1, 8, 10-11]. In Europe, including Poland, in addition to the use of sugar beet for sugar purposes, it is possible to use it for biogas purposes. Sugar beets are considered to be a very efficient substrate [1]. In seed company experiments, it was found that so-called energy beet gains yield (roots and leaves) even from 130 to $150 \mathrm{Mg} \cdot \mathrm{ha}^{-1}[12]$. In addition, the dry weight of beet is about $94 \%$ carbohydrates undergoing a rapid fermentation process, and $80 \%$ of the organic mass decomposes completely. In addition to the above advantages, it is also necessary to add a high level of biogas yield in which the gas peak is reached after 12 hours and a very short total time of fermentation of the substrate, amounting to about 15 days. For comparison, in the case of maize, these values are respectively 12 and 90 days $[1,5,12-14]$. Although the methane fermentation process has been known for a long time, the use of new agricultural substrates will allow to increase the efficiency of agricultural biogas plants [15]. Vindis et al. [16-17] claim that the use of beets in a mixture with other substrates accelerates the fermentation process and improves the quality of the produced biogas. In addition, taking into account Polish conditions, the energetic use of sugar beet is part of the "Innovative Energy. Energy Agriculture ", program adopted by the Polish government in 2009. One of the assumptions of this plan is to base the functioning of agricultural biogas plants on plant products [18-23].

Regardless of the plant production system, the determinant of its profitability, and as a result of biogas yield, is the biomass yield per hectare $[1,24]$. Sugar beet with leaves is the most yielding plant, it also has high energy efficiency parameters. These features also mean that sugar beets can be successfully used for biogas production.

In the technologies of alternative use of sugar beet for biogas, in European countries, as well as in Poland, significant technical progress is noted, especially in the field of storage and preparation of substrates for biogas plants $[25,26,27,28]$. The substrate must be available throughout the all year while the harvest is carried out seasonally. The possibility of year-round storage of roots is in the use of flexible silos or open tanks for this purpose [25]. In addition, many varieties with different usable, sugar, normal and highly yielding types are available in sugar beet production. The sugar type is characterized by an increased sugar content and low content of technologically harmful ingredients with medium or slightly lower yields. The normal type is characterized by average sugar and usually higher yield. The highly yielding type shows a relatively low sugar content and high root yield. In the case of sugar beet intended for energy purposes, the quality parameters related to sugar production, as well as the content of molasses, are not the most important [25, 29]. Farmers, who want to dedicate their roots to energy purposes do not have to be limited by technological quality traits. It gives new opportunities to growers as well as breeders.

Using sugar beet as a biogas substrate is a rather new endeavor [2, 30]. Currently, there is no experimentally verified evaluation of the suitability of sugar beet for the production of biogas depending on the storage time and sugar content. There are no research results that would determine the impact of these two parameters on the efficiency of biogas and methane production. Effective use of beets as a substrate for biogas, therefore, requires indication 
whether the storage will allow to maintain good quality parameters of the preserved mass, thus obtaining high methane efficiency and whether the sugar content determines the methane yield.

Therefore, the aim of the work was to analyze the usefulness of sugar beets for the production of biogas, taking into account the storage time and sugar content in the roots.

\section{Material and methods}

The research included methane efficiency analysis. The substrates used in the experiment were the sugar beet roots mixed with swine and cattle slurry. Sugar beets with different sugar content were used for analysis, which were marked with symbols: A - 17.6\%, B - 19.60\%.

The analysis of biogas yields was carried out on the following 3 dates:

- T0 - roots not stored (fresh),

- T1 - after 43 days of storage,

- T2 - after 89 days of storage.

The roots were stored as a whole (no crushed) in hermetically sealed bags (elastic silos) under anaerobic conditions. The root weight in a single silo was from $6.8 \mathrm{~kg}$ to $7.3 \mathrm{~kg}$. Samples prepared in this manner were stored under a roof at ambient temperature.

The sugar beets roots before each methane fermentation process were crushed into parts with a diameter not exceeding $5 \mathrm{~mm}$. A representative sample was collected from the prepared in this way "mousse". The samples were checked in terms of:

- dry matter,

- organic dry matter,

- $\mathrm{pH}$.

The sample in the methane fermentation process were substrates in the following proportions:

- $50 \mathrm{~g}$ of sugar beet of a given group,

- 500 g slurry,

- $100 \mathrm{~g}$ inoculum.

The control consisted of slurry without added sugar beet.

The experiment was carried out in accordance with the German standard DIN 38414-S8 in a multi-chamber fermentation station, based on the eudiometric system. The process took place in mesophilic conditions, at a temperature of $36^{\circ} \mathrm{C} \pm 2$. Reactors with a capacity of 2 $\mathrm{dm}^{3}$, were placed in a tank filled with water, in which a constant temperature was maintained (fig. 1) [19].

The produced biogas was stored in measuring cylinders with a capacity of $1200 \mathrm{ml}$. The volume of the produced biogas was measured every $24 \mathrm{~h}$. Using the MSMR-4 gas analyzer from ALTER S.A, the composition of the produced biogas was checked. The concentrations of gases such as $\mathrm{CH}_{4}, \mathrm{CO}_{2}, \mathrm{NH}_{3}, \mathrm{O}_{2}, \mathrm{H}_{2} \mathrm{~S}$. were measured. The experiment were terminated when for at least 3 days, the yield of biogas produced was less than $0.05 \mathrm{dm}^{3}$ per day. 


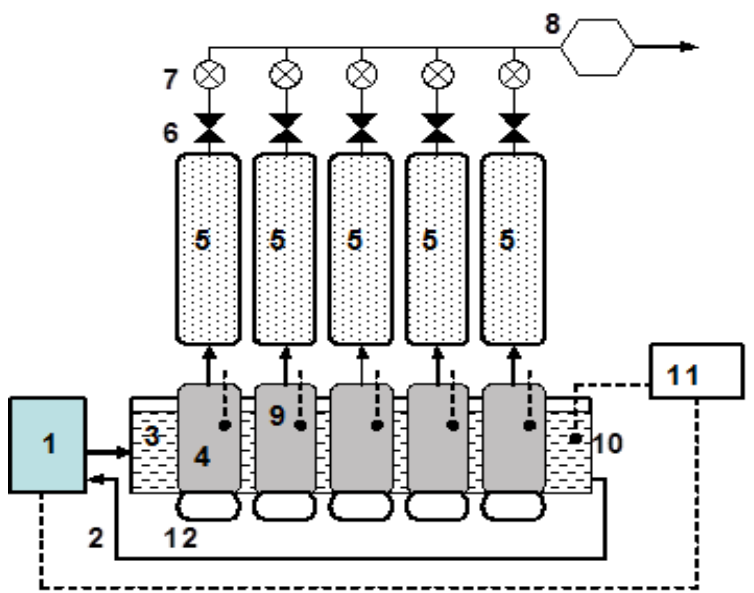

Fig. 1. Scheme of biofermentor for biogas production research (5-chamber section): 1 - water heater with temperature regulator, 2 - insulated conductors of calefaction liquid, 3 - water coat with temp. $36-38^{\circ} \mathrm{C}, 4$ - biofermentor with charge capacity $2 \mathrm{dm} 3,5$ - biogas reservoir, 6 cutting off valves, 7 - gas flow meters, 8 - gaseous analyzers $\left(\mathrm{CH}_{4}, \mathrm{CO}_{2}, \mathrm{NH}_{3}, \mathrm{O}_{2}, \mathrm{H}_{2} \mathrm{~S}\right), 9-\mathrm{pH}$ sensors, 10 - temperature sensor, 11 - steering - recording central station, 12 - charge magnetic mixers [19].

\section{Results}

\subsection{Substrates parameters}

Before each fermentation process the basic parameters of sugar beets, such as dry matter, organic dry matter and $\mathrm{pH}$ were checked.

Table 1. Parameters of substrates in particular dates.

\begin{tabular}{|c|c|c|c|c|}
\hline $\begin{array}{c}\text { Storage } \\
\text { time }\end{array}$ & Substrate & DM [\%] & ODM [\%] & pH \\
\hline \multirow{2}{*}{ T0 } & Control (slurry) & 3.14 & 66.45 & 7.44 \\
\hline \multirow{2}{*}{ T1 } & Sugar beets A & 25.57 & 93.21 & 5.96 \\
\cline { 2 - 5 } & Sugar beets B & 26.76 & 94.33 & 6.21 \\
\cline { 2 - 5 } & Sugar beets A & 19.80 & 92.23 & 4.38 \\
\cline { 2 - 5 } T2 & Sugar beets B & 21.55 & 93.79 & 4.17 \\
\cline { 2 - 5 } & Sugar beets A & 17.24 & 82.62 & 4.95 \\
\hline \multirow{2}{*}{ Sugar beets B } & 18.88 & 91.39 & 4.73 \\
\hline
\end{tabular}

The results are summarized in Table 1. The analysis shows that root storage affects the decrease of dry matter and organic matter as well as the $\mathrm{pH}$ of beets. This is because during storage a part of the dry matter undergoes decomposition to $\mathrm{CO}_{2}$ and $\mathrm{H}_{2} \mathrm{O}$. In the case of roots with a lower sugar content, the dry matter after 12 weeks of storage decreased by $32.6 \%$, while in the case of roots with a higher sugar content by $29.5 \%$. Storage of roots also contributed to the reduction of their organic dry matter. The value of the roots' $\mathrm{pH}$ also decreased during storage, which clearly indicates to the processes of substrate degradation and the formation of organic acids that caused acidification of the substrates. 


\subsection{Fermentation process}

The experiment also included an analysis of the course of the methane fermentation process. Figure 2 presents an example chart of the biogas fermentation process of sugar beet with a sugar content of $19.6 \%$ stored for 89 days. The analysis shows that beetroots decisively ferment faster compared to, for example, cattle manure (Figure 3) and are an example of a rapidly decomposing substrate intended for biogas plants [19]. The largest biogas production was recorded in the first days after the start of fermentation. The whole fermentation process also ended much faster (after 29 days) in relation to cattle manure, where biogas production lasted for more than 50 days [19]. In addition, after three days, the amount of methane in biogas has exceeded the amount of other gases.

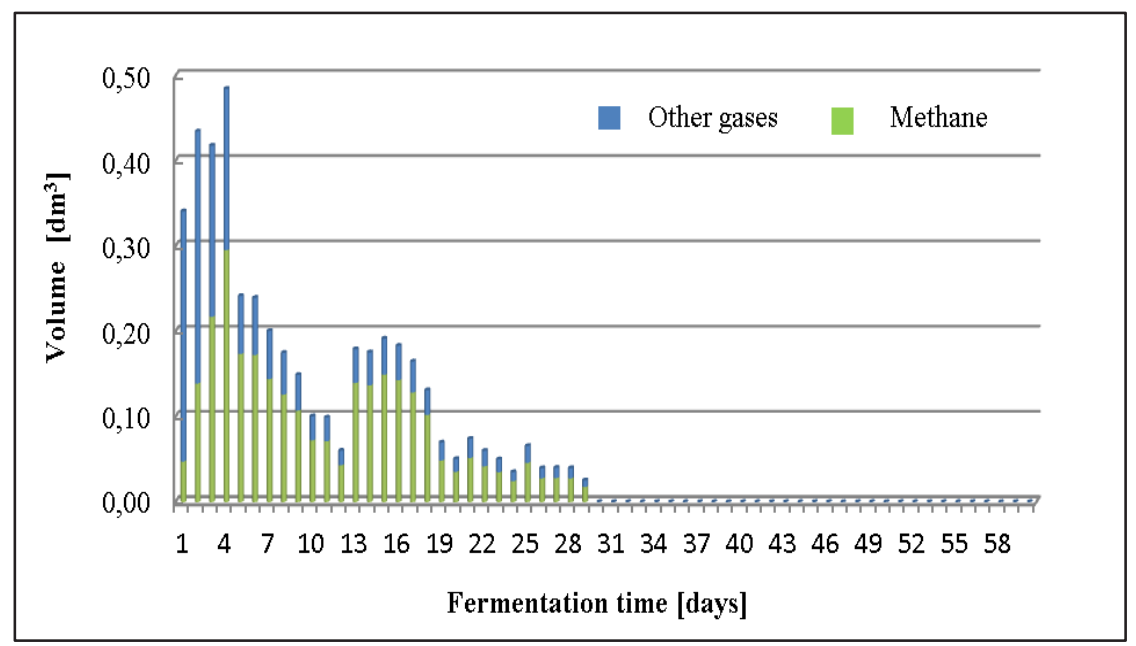

Fig. 2. Daily biogas production from sugar beets with $19.6 \%$ sugar content after 89 days of storage.

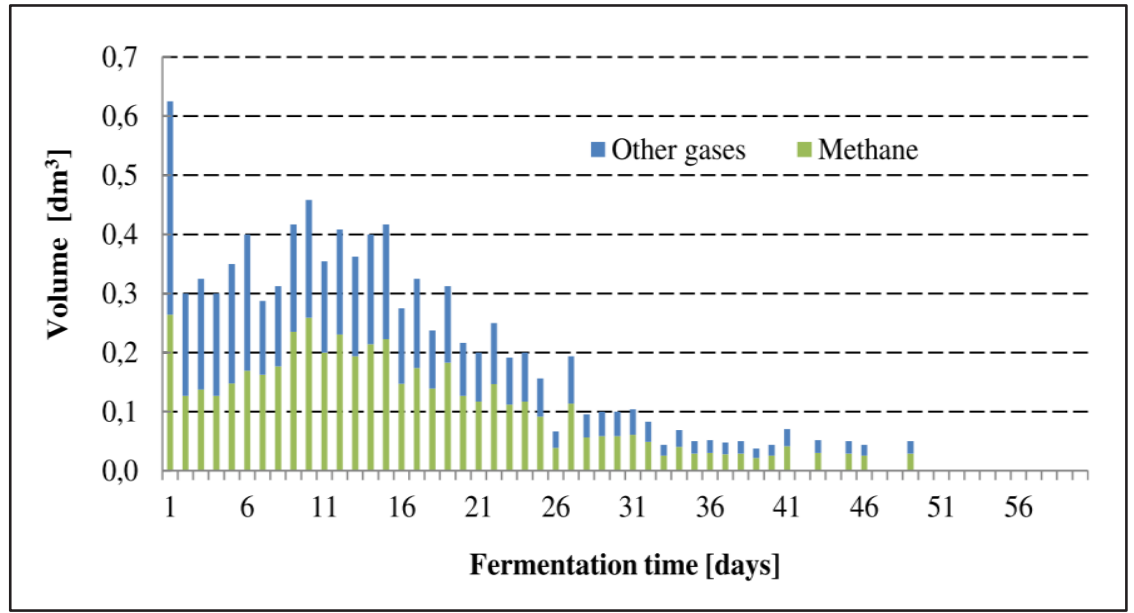

Fig. 3. Daily biogas production from cattle manure [19].

This distribution of biogas production, typical for sugar beets, occurred in the case of roots stored for 43 and 89 days. Figure 4 shows the cumulative methane production from fresh beets. 


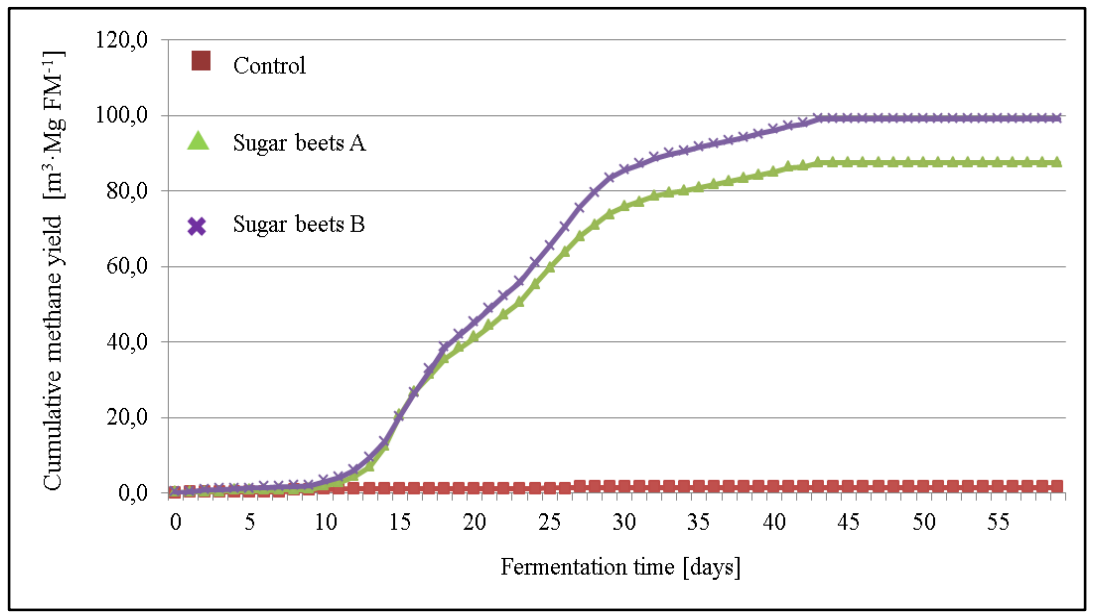

Fig. 4. Cumulative methane production from $\mathrm{Mg}$ of fresh sugar beets fresh matter.

The graph (fig. 4) shows that the beets have started fermentation scarcely on day 13 . The reason for the initial difficulty in the starting phase of fermentation was related with acidification of the samples. In this case, some phenomena of methane bacteria inhibition has occurred (for almost 2 weeks) and thus the production of biomethane may be stopped. Fresh sugar beet roots are a difficult substrate for fermentation, and the accumulation of readily available sugars can result in dynamic hydrolysis and, as a consequence, acidification of the environment. Most likely, this was the case during the fermentation process of fresh beet tests, because the decrease in $\mathrm{pH}$ below 6.8 stops the activity of methanogens and the methane production. This $\mathrm{CH}_{4}$ production starts again while (after organic acids consumption) $\mathrm{pH}$ raises over 6.8 .

\subsection{Biomethane production}

Table 2 shows amount of biogas, methane and concentration of methane reached from each sample. Higher sugar content in sugar beets has positively influenced methane concentrations.

Table 2. Cumulative methane production and concentration.

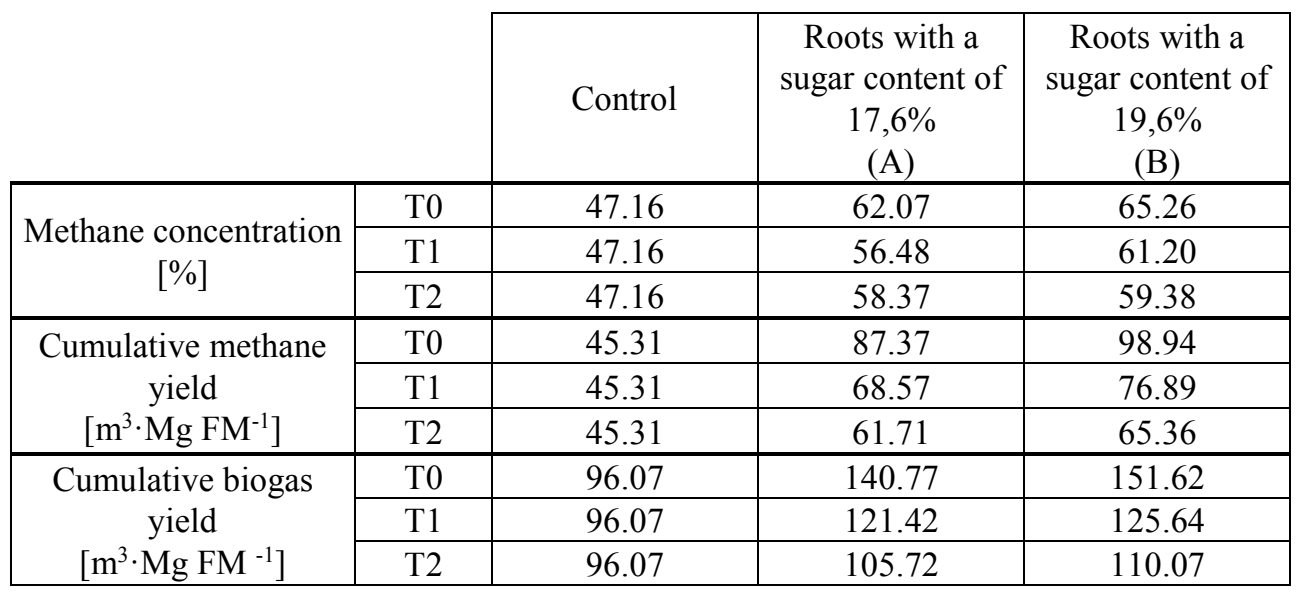


In all analyzed dates, roots with a sugar content of $19.6 \%$ were characterized by higher concentration of methane by $2 \%$ to even $8 \%$ in the case of roots stored for 43 days. A similar relationship was found in the case of accumulated methane and accumulated biogas. The cumulative production of methane obtained from beets with a higher sugar content was even $12 \%$ higher than in the case of beets with a sugar content of $17.6 \%$ (fresh roots). Differences in the production of cumulated biogas between beets with different sugar content ranged from 4 to $8 \%$. The analysis also have showed that the length of root storage contributes to the reduction of biogas and methane potential as well as concentration of methane.

\section{Conclusions}

1. The obtained research results clearly indicate that sugar beet is an efficient substrate for biogas production.

2. It can be concluded that the sugar content affects the quality of biogas produced, because there was a tendency to increase methane production along with a higher sugar content in the sugar beet roots.

3. The storage of sugar beet roots contributes to the decrease in biogas production, while at the same time it causes a decrease in its quality most probably due to the decomposition of organic matter with time.

4. The storage time causes that the content of dry matter and dry organic matter decreases, and with their decrease, the amount of biogas produced decreases respectively.

5. Fresh beet roots are a difficult substrate for fermentation due to the tendency for dynamic hydrolysis and in consequence the environment acidification. It should be remembered that the $\mathrm{pH}$ decreased below 6.8 stops methanogenic bacteria activity and then methane production.

\section{References}

1. J. Przybył, N. Mioduszewska, J. Dach, K. Pilarski, Agricultural Engineering, 7(132), 131-140 (2011)

2. S. Sauthoff, O. Musshoff, M. Danne, F. Anastassiadis, Biomass Bioenerg, 90, 163-172 (2016)

3. R. Gaj, A. Budka, A. Niewiadomska, J. Przybył, N. Mioduszewska, J. Elem., 20(3), 571-584, (2015)

4. A. Niewiadomska, R. Gaj, J. Przybył, A. Budka, N. Mioduszewska, A. WolnaMaruwka, Pol. J. Environ. Stud., 25(5), 1803-1812 (2016)

5. A. Jacobs, W. Brauer-Siebrecht, O. Christen, P. Götze, H.-J. Koch, J. Rücknagel, B.Märländer, Field Crops Research, 196, 75-84 (2016)

6. P. Okoń; J. Rudowicz-Nawrocka; P. Boniecki; K. Koszela; M. Zaborowicz; P. Idziaszek; K. Górna; N. Mioduszewska, Proc. SPIE 10420, 1042007 (21 July 2017); doi: $10.1117 / 12.2281724$

7. A. Jacobs, S. Auburger, E. Bahrs, W. Brauer-Siebrecht, O. Christen, P. Götze, H.-J. Koch, J. Rücknagel, B.Märländer, Appl Energ, 190, 114-121 (2017)

8. A. Jacobs, S. Auburger, E. Bahrs, W. Brauer-Siebrecht, O. Christen, P. Götze, H.-J. Koch, O. Mußhoff, J. Rücknagel, B. Märländer, Agr Syst, 157, 270-278 (2017) 
9. E. Kumanowska, M. U. Saldaña, S. Zielonka, H. Oechsner, Bioresource Technol, 245, 876-883 (2017)

10. C. Dorado, R. G. Cameron, K. Cooper, Biocatalysis and Agricultural Biotechnology, 11, 26-33 (2017)

11. K. Aboudi, C.J. Álvarez-Gallego, L.I. Romero-García, Sci Total Environ, 586, 438-445 (2017)

12. J. Przybył, N. Mioduszewska, Ocena zewnętrznej jakości korzeni buraków cukrowych z uwzględnieniem zróżnicowanego wykorzystania plonu. Nowoczesne metody oceny surowców rolniczych. Rzeszów. (2011), ISBN 978-83-933173-4-9, 167-178

13. B. Demirel, P. Scherer, Biomass Bioenerg, 32, 203-209 (2008)

14. V. Kryvoruchko, A. Machmuller, V. Bodiroza, B. Amon, T. Amon, Biomass Bioenerg, 33, 620-627 (2009)

15. W. Czekała, A. Smurzyńska, M. Cieślik, P. Boniecki, K. Kozłowski, Energy and Clean Technologies Conference Proceedings, International Multidisciplinary Scientific GeoConference-SGEM III, 227-233 (2016)

16. P. Vindis, B. Mursec, C. Rozman, M. Janzekovic, F. Cus, Journal of Achievements in Materials and Manufacturing Engineering. 28 (1), 99-102 (2008)

17. P. Vindis, B. Mursec, C. Rozman, M. Janzekovic, F. Cus, Journal of Achievements in Materials and Manufacturing Engineering, Vol. 35 No 2, 191-196 (2009)

18. MRiRW, Założenia Programu rozwoju biogazowni rolniczych, Warszawa (2009)

19. J. Dach, P. Boniecki, J. Przyby1, D. Janczak, A. Lewicki, W. Czekała, K. Witaszek, P. C. Rodríguez Carmona, M. Cieślik, Energy, 69, 34-38 (2014)

20. A. Piwowar, M. Dzikuć, J. Adamczyk, Renew Sust Energ Rev, 58, 69-74 (2016)

21. B. Igliński, R. Buczkowski, M. Cichosz, Renew Sust Energ Rev, 50, 686-695 (2015)

22. J. Chodkowska-Miszczuk, D. Szymańska, Renew Sust Energ Rev, 20, 514-518 (2013)

23. J. Chodkowska-Miszczuk, D. Szymańska, Renew Sust Energ Rev, 15, 4242-4247 (2011)

24. G. Niedbała, N. Mioduszewska, W. Mueller, P. Boniecki, D. Wojcieszak, K. Koszela, S. Kujawa, R. J. Kozłowski, K. Przybył, Proc. SPIE 10033, Eighth International Conference on Digital Image Processing (ICDIP 2016), 100332M (29 August 2016); doi: $10.1117 / 12.2244875$

25. N. Mioduszewska, J. Przybył, D. Wojcieszak, M. Adamski, T. Wojciechowski, Current problems of agricultural engineering, University of Life Sciences in Poznan, Editors: J. Przybył, M. Lipiński, 284-292 (2015)

26. M.-L. Hillion, R. Moscoviz, E. Trably, Y. Leblanc, N. Bernet, M. Torrijos, R. Escudié, Waste Manage, 71, 147-155 (2018)

27. S. Ahmed, M. Kazda, Anaerobe, 46, 114-121 (2017)

28. S. U. Larsen, K. Hjort-Gregersen, A. H. Vazifehkhoran, J. Mi Triolo, Bioresource Technolog, 245, 106-115 (2017)

29. J. M. Vargas-Ramirez, D. M. Haagenson, S. W. Pryor, D. P. Wiesenborn, Biomass Bioenerg, 85, 135-143 (2016)

30. M. Fugol, K. Pilsarski, Agricultural Engineering, 5(130), 63-71 (2011) 